\title{
Tapaus-verrokkitutkimus työtapaturmien ja ammattitautien riskitekijöistä suomalaisten maidontuottajien keskuudessa
}

\author{
Janne Karttunen ${ }^{1)}$ ja Risto Rautiainen ${ }^{2)}$ \\ ${ }^{1)}$ TTS - Työtehoseura, PL 5, 05201 Rajamäki, janne.karttunen@tts.fi \\ 2) The University of Nebraska, College of Public Health, Department of Environmental, Agricultural \\ and Occupational Health, Omaha, Nebraska 68105, USA sekä Maa- ja elintarviketalouden tutki- \\ muskeskus,rrautiainen@unmc.edu
}

\section{Tiivistelmä}

Tutkimuksen tavoitteena oli tunnistaa työtapaturmien ja ammattitautien esiintyvyyden suhteen toisistaan merkittävästi poikkeaville maatalousyrittäjille tyypillisiä riskitekijöitä ja suojelevia tekijöitä. Tutkimus rahoitettiin Maatalousyrittäjien eläkelaitoksen työturvallisuusapurahalla.

Kohdehenkilöiden tuli olla maidontuottajia, olla peltoalan suhteen vähintään keskikokoisilta tiloilta, kuulua työterveyshuoltoon ja olla ollut vähintään kymmenen vuotta vakuutettuina. Lisäksi tilalla tuli olla vakuutettuna tasan kaksi yrittäjää.

Tutkimukseen soveltuvat vapaaehtoiset henkilöt allekirjoittivat henkilökohtaisen tiedote- ja suostumusasiakirjan. Kohdehenkilöille lähetettiin saatekirje ja kyselylomake, jonka vastaukset kerättiin puhelimitse. Lopullinen tapaus-ryhmä koostui 19 pariskunnasta, joissa kummallekin yrittäjälle oli korvattu vakuutetun työuran aikana vähintään neljä työtapaturmaa tai ammattitautia. Verrokki-ryhmän 12 pariskunnassa kummallekaan yrittäjälle ei ollut korvattu yhtään vahinkoa.

Kartoitetuista 92 muuttujasta 34 oli vakioimattomassa logistisessa regressiomallissa tilastollisesti suuntaa-antavasti $(\mathrm{p}<0,10)$ ja niistä 25 oli merkitsevästi $(\mathrm{p}<0,05)$ yhteydessä kohonneeseen työtapaturmariskiin. Ammattitautiriskin suhteen vastaavia muuttujia oli 21 ja 14 kappaletta. Tilan tukialueen ja vakuutusvuosien (molemmat merkitseviä riskitekijöitä) suhteen vakioituihin malleihin otettiin mukaan kaikki muut yksittäin tarkasteltuina vähintään suuntaa-antavasti merkitsevät muuttujat.

Seuraavat 13 muuttujaa olivat malleissa merkitsevästi yhteydessä kohonneeseen työtapaturmariskiin (alenevassa merkittävyysjärjestyksessä): alentuneeksi koettu nykyinen työkyky, vähintään satunnainen alkoholin käyttö, hylättyjen korvaushakemusten olemassaolo, useimpien maatilatalouden töiden teko pariskunnan yhteisvoimin, hengityselin- tai tuki- ja liikuntaelinsairauksien tai kiputilojen olemassaolo, ylioppilastutkinnon puuttuminen, lomittajien puutteellinen ohjeistus, riittämätön maataloustöiltä jäävä vapaa-aika, kuivan heinän päivittäinen käyttö nautojen ruokinnassa, aktiivinen sosiaalinen elämä, melko tai erittäin suureksi koettu ammattitautiriski, sarvekas karja ja päivittäinen lääkkeiden käyttö. Riskitekijöiden vetosuhteet vaihtelivat vakioiduissa malleissa 5.03-33.33 välillä.

Kohonneeseen ammattitautiriskiin olivat merkitsevästi yhteydessä tule-sairauksien tai kiputilojen olemassaolo, useimpien maatilatalouden töiden teko pariskunnan yhteisvoimin, päivittäinen lääkkeiden käyttö sekä aktiivinen sosiaalinen elämä (vetosuhteet välillä 15.49-26.75).

Tutkimuksen heikkous oli osallistujien odotettua alhaisempi määrä, mikä rajoitti aineiston tilastollista tarkastelua. Vahvuus oli ainutlaatuinen tapa muodostaa tutkimusryhmät, mikä edisti ryhmien välisten erojen esilletuloa.

Todettujen riskitekijöiden avulla laadittiin kuvaukset kohonneen ja alentuneen riskin omaavista maidontuottajista. Suuri osa riskitekijöistä soveltuu myös muiden tuotantosuuntien edustajien ryhmittelyyn ja työsuojelutoimenpiteiden tarkennettuun kohdentamiseen, mikä voi lisätä toimenpiteiden kustannustehokkuutta.

Asiasanat: ammattitauti, maatalous, riski, työtapaturma, vakuutus 


\section{Johdanto}

Työtapaturmia ja ammattitauteja voidaan torjua reagoivasti (reaktiivisesti) eli otetaan oppia sattuneista vahingoista. Ennakoivassa (proaktiivisessa) torjuntatavassa torjutaan vahinkoihin johtavien vaaratekijöiden eli riskitekijöiden syntymistä. Riskitekijät voidaan Lappalaisen ja Saarelan (2003) mukaan ryhmitellä teknisiin ja fyysisiin, henkilöiden toimintaan liittyviin sekä organisatorisiin tekijöihin.

Maatilatalous on työtapaturmien ja ammattitautien määrän ja vakavuuden suhteen yksi riskialtteimmista toimialoista maailmanlaajuisesti ja myös Suomessa (Rautiainen ym. 2005, Rautiainen ja Reynolds 2002). Virtasen ym. (2003) mukaan työtapaturmariski on kohonnut päätoimisilla suomalaisilla maatalousyrittäjillä, jotka ovat miehiä, puhuvat äidinkielenään suomea (vs. ruotsi), harjoittavat nautakarja- tai sikataloutta ja omistavat keskikokoista suuremman tilan.

Karttunen ja Rautiainen (2010) tarkastelivat suomalaisille maatalousyrittäjille korvattujen työtapaturmien ja ammattitautien riskitekijöitä hallinnollisen tilastoaineiston avulla. Muun muassa seuraavat maatalousyrittäjään tai -yritykseen liittyvät muuttujat olivat kolmen vuoden tarkastelujakson perusteella merkitsevästi yhteydessä kohonneeseen työtapaturmariskiin: korkea ikä, sukupuolena mies, äidinkielenä suomi, suuri peltoala, maatalousyrittäjien työterveyshuollon (MTH) jäsenyys sekä tietyt päätuotantosuunnat ja erityisesti karjatalouden harjoittaminen (vs. viljantuotanto). Näistä muuttujista tilan peltoala, MTH-jäsenyys ja karjatalouden harjoittaminen olivat yhteydessä myös kohonneeseen ammattitautiriskiin.

Kolmen vuoden tarkastelujakso riitti edellä mainitussa tutkimuksessa osoittamaan, että suuri määrä korvatuista työtapaturmista ja ammattitaudeista kasaantuu pienelle osalle vakuutetuista. Lisäksi vahingottomien suhteellinen osuus lähtee laskusuuntaan, kun tarkastelujaksoa pidennetään tyypillisestä yhdestä vuodesta. Visserin ym. (2007) mukaan tapaturmat kasaantuvat osalle ihmisistä, jotka kannattaa ottaa kohderyhmiksi vahinkojen torjuntatoimenpiteille.

Karttunen ja Rautiainen (2010) suosittelevat, että maatalousyrittäjiä kannattaisi jatkossa ryhmitellä todettujen riskitekijöiden suhteen, jotta neuvonta-, koulutus- ja tutkimusresursseja sekä vakuutusteknisiä toimenpiteitä kyettäisiin kohdentamaan aikaisempaa tuloksellisemmin ja kustannustehokkaammin sekä varhaisessa vaiheessa työuraa.

Lehtolan ym. (2009) meta-analyysin mukaan maatilataloudessa sattuvien työtapaturmien ja ammattitautien määrien ja kustannusten vähentämiseksi tehdyillä toimenpiteillä ei ole tähän asti saavutettu kuin harvoja mitattavissa olevia tuloksia. Edellä kuvattua vahinkojen kasaantumisilmiötä ei kuitenkaan ole tähän mennessä kunnolla tiedostettu ja hyödynnetty maatalouden työturvallisuustyössä.

\section{Tutkimuksen tavoite}

Tutkimuksen päätavoitteena oli tunnistaa MATA-vahinkojen (työtapaturmien ja ammattitautien) esiintyvyyden suhteen merkittävästi toisistaan poikkeaville MYEL-vakuutetuille maidontuottajille tyypillisiä työtapaturmille ja ammattitaudeille altistavia sekä niiltä suojaavia tekijöitä. Näitä tekijöitä tuli etsiä tilan kaikkien töiden organisoinnista, teknisestä ja fyysisestä tuotantoympäristöstä sekä yrittäjien henkilökohtaisesta toiminnasta ja asenteista.

Tutkimuksen jatkotavoitteena oli edellä mainittujen tekijöiden tunnistamisen avulla määrittää erityisesti maidontuottajien sekä yleisemmin kaikkien maatalousyrittäjien keskuudesta kohderyhmiä työsuojelutoimenpiteille: tuli määritellä viljelijäryhmiä, joilla on merkittävästi kasvanut vahinkoriski ja toisaalta ryhmiä, joilla riski on alentunut.

\section{Aineisto ja menetelmät}

Tutkimusryhmien muodostamisessa käytettiin deidentifioituja MYEL-, MTH- ja Tiken maatilarekisterin tietoja, joista viimeksi mainitut olivat vuodelta 2002. Tutkimukseen ehdolla olleet henkilöt olivat olleet ainakin vuonna 2002 maidontuottajia, olivat peltoalan suhteen vähintään keskikokoisilta tiloilta, kuuluivat MTH:oon ja olivat olleet 7/2008 mennessä vähintään kymmenen vuotta vakuutettuina. Melan toimesta tarkistettiin, että kaikki henkilöt olivat syksyllä 2010 edelleen MYEL-vakuutettuja. Koska tutkimukseen haluttiin saada tyypillisiä viljelijäpariskuntia, tuli tilalla olla vakuutettuna tasan kaksi yrittäjää, jotka olivat eri sukupuolta ja suunnilleen samanikäisiä.

Tutkimusasetelmaksi valittiin tapaus-verrokkitutkimus, jonka tapaus-ryhmään (vahingoittuneet) valittiin ehdolle pariskuntia, joissa kummallekin yrittäjälle oli tilastoitu 7/2008 mennessä vähintään viisi MATA-vahinkoa. Verrokki-ryhmään (vahingottomat) ehdolle valituissa pariskunnissa kummallekaan yrittäjälle ei ollut tilastoitu yhtään vahinkoa MYEL-vakuutetun työhistorian aikana. 
Tutkimusryhmiin alustavasti sopiville henkilöille lähetettiin Melasta henkilökohtainen tiedoteja suostumusasiakirja. Asiakirjan lopussa oli suostumuslomake ja sen liitteenä oli palautuskuori. Suostumuslomake pyydettiin palauttamaan allekirjoitettuna Melaan, jos tilan molemmat yrittäjät kuuluivat edelleen kohderyhmään, halusivat vapaaehtoisesti osallistua tutkimukseen ja antoivat Melalle luvan luovuttaa hankkeen vastuututkijalle nimi- ja osoitetietojensa lisäksi tiedot heille korvatuista vahingoista. Asiakirja ja palautuskuori lähetettiin kaikille kohdehenkilöille kaksi kertaa.

Vastuututkija lähetti allekirjoitetun suostumuksensa antaneille maidontuottajapariskunnille saatekirjeen ja 12-sivuisen kyselylomakkeen, jossa oli 85 monivalintakysymystä jaoteltuna 15 ryhmään. Tutkimuskysymysten muotoiluun osallistui neljä maatilatalouden työturvallisuuden ja -terveyden asiantuntijaa. Kysymysten ja tutkimusmenetelmän toimivuus oli testattu koetilan kanssa.

Saatekirjeet ja kyselylomakkeet lähetettiin kolmessa erässä noin viikon välein. Noin kahden viikon kuluttua siitä, kun lomakkeen voitiin olettaa saapuneen perille, vastuututkija soitti tilalle ja keräsi kyselyvastaukset sekä 15 täydentävää tietoa.

Vastausaineisto siirrettiin sähköiseen muotoon MS Exceliin, jossa muuttujaluokkia yhdistettiin lähinnä dikotomisoimalla tyypillisesti neliportaisia vastauksia kaksiportaisiksi. Dikotomisoinnin rajaarvona toimi yleensä vastausten mediaaniluku.

Puhdistettu aineisto siirrettiin tilasto-ohjelmaan SAS 9.2 (SAS Institute Inc 2008). Tilastoohjelman avulla selvitettiin työtapaturmien ja ammattitautien esiintyvyyttä selittävien muuttujien eli potentiaalisten riskitekijöiden vetosuhteet (OR) ja luottamusvälit (CI) logistisella regressioanalyysillä. Riskitekijät selvitettiin ensin yli 90 prosentin $(\mathrm{p}<0,10)$ ja sen jälkeen yli 95 prosentin $(\mathrm{p}<0,05)$ luotettavuustasolla eli alle kymmenen ja alle viiden prosentin erehtymisriskitasoilla.

\section{Tulokset ja tulosten tarkastelu}

Lypsykarjataloudessa 2000-luvulla voimakkaana jatkuneen rakennemuutoksen vuoksi osa tutkimukseen ehdolla olleista henkilöistä ei kyselyhetkellä enää ollut aktiivinen maidontuottaja, vaikka oli vielä MYEL-vakuutettu. Käyttökelpoiset vastaukset saatiin yhteensä 19 vahingoittuneelta (tapaus-ryhmä) ja 12 vahingottomalta pariskunnalta (verrokki-ryhmä) eli yhteensä 31 maitotilalta ja 62 henkilöltä.

\section{Tulosten yleistettävyys}

Tavanomaisille kyselytutkimuksille tyypillisen vastauskadon tarkastelu ei ole mahdollista tässä aineistossa. Toisaalta se ei ole tarpeen tapaus-verrokki-tutkimusasetelmassa, jossa aineisto on jo lähtökohtaisesti valikoitunutta tutkittaessa tietyn ilmiön suhteen ääripäitä edustavia henkilöitä.

Tutkimusaineiston maidontuottajia ja heidän tilojaan voidaan verrata kaikkiin maamme maidontuottajiin ja maitotiloihin muutamien keskeisten muuttujien suhteen. Aineiston tiloilla oli lehmiä keskimäärin 30 kappaletta. Maamme maitotiloilla oli tutkimuksessa toteutetun kyselyn hetkellä - vuoden 2010 lopussa - lehmiä keskimäärin 27 kappaletta (Tike 2011).

Aineiston tiloilla oli omaa peltoa keskimäärin 31 hehtaaria, vuokrapeltoa keskimäärin 19 hehtaaria ja metsää 74 hehtaaria. Vuokrapeltoa oli 27 tilalla (87 \% tiloista) ja metsää oli kaikilla tiloilla. Maamme maitotiloilla oli vuonna 2010 keskimäärin 50 hehtaaria omaa peltoa, 23 hehtaaria vuokrapeltoa ja metsää 65 hehtaaria (Tike 2011). Maamme maitotiloista 83 prosentilla oli vuokrapeltoa ja 99 prosentilla oli metsää vuonna 2010 (Tike 2011).

Aineiston maidontuottajien keski-ikä oli 49,8 vuotta ja se oli likipitäen sama kuin maamme kaikkien maatalousyrittäjien keski-ikä, joka oli 50,6 vuotta vuonna 2010 (Tike 2011). Julkista tietoa maamme aktiivisten maidontuottajien keski-iästä ei ole käytettävissä, mutta Tiken (2011) mukaan kotieläintuotantoa päätuotantosuuntanaan harjoittavien tilojen viljelijät ovat keskimäärin hieman nuorempia kuin kasvintuotantoa harjoittavilla tiloilla.

Näin ollen aineiston maidontuottajien voidaan arvioida kuvaavan keski-ikänsä puolesta hyvin maamme maidontuottajia. Aineiston tilat kuvaavat lehmämäärän ja metsäalan suhteen parhaiten hieman keskikokoista suurempia ja oman sekä vuokralla olevan peltoalan suhteen hieman keskikokoista pienempiä maitotiloja maassamme.

\section{Korvatut MATA-vahingot}

Tapaus-ryhmään kuuluneilla 19 pariskunnalla oli MATA-rekisterissä merkintä yhteensä 360 MATAvahingosta (työtapaturmasta tai ammattitaudista). Ensimmäinen merkintä oli tullut keskimäärin kuudennen vakuutusvuoden aikana (minimi 1., maksimi 21., mediaani 6. vakuutusvuosi). 
Vahinkoilmoituksista 77 (21\%) oli joko hylätty, rauetettu tai vain tutkimuskulut oli korvattu. Tapaus-ryhmäläisille oli lopulta korvattu yhteensä 283 vahinkoa. Vahinkoilmoitusten korvausprosentti vaihteli ryhmäläisillä 44 ja 100 välillä. Jokaiselle oli korvattu vähintään neljä MATA-vahinkoa. Tätä pidettiin lopulta alarajana sille, että tapaus-ryhmään alun perin kuulunutta henkilöä, hänen puolisoaan ja heidän tilaansa koskevat vastaukset otettiin mukaan tutkimukseen.

Korvatuista vahingoista 263 oli työtapaturmia, joita oli sattunut keskimäärin seitsemän henkilöä kohti (minimi 1 ja maksimi 19, mediaani ja moodi 5). Lisäksi tapaus-ryhmäläisille oli korvattu yhteensä 20 ammattitautia: 1-3 kpl henkilöä kohti ja 1-4 kpl pariskuntaa kohti.

Korvatuista MATA-vahingoista oli seurauksiltaan lieviä 239 (84,5\%), eli niistä oli aiheutunut korkeintaan 30 vuorokauden sairausloma. Vahingoista oli vakavia $44(15,5 \%)$, eli niistä oli aiheutunut vähintään 31 vuorokauden sairausloma. Lievien työtapaturmien osuus oli tässä valikoituneessa aineistossa suurempi kuin Sinisalon (2007) tutkimuksessa, jossa niitä oli 77,5 prosenttia kaikista maidontuottajille vuonna 2005 korvatuista työtapaturmista.

Työtapaturmista 167 (63\%) oli korvattu miehille ja 96 (37\%) naisille. Työtapaturmista 171 $(65 \%)$ oli sattunut karjanhoidon eri työtehtävissä, ja näistä tapauksista 87 (51 \%) oli sattunut miehille ja 84 (49\%) naisille. Työtapaturmien jakaantuminen tässä aineistossa miesten ja naisten kesken yleensä ja erityisesti karjanhoitotöissä on linjassa sen kanssa, mitä tiedetään yrittäjäpariskuntien keskinäisestä töiden jaosta suomalaisilla lypsykarjatiloilla (Karttunen 2011).

Tapaus-ryhmäläisille korvatuista 20 ammattitaudista miehille oli korvattu kahdeksan (40 \%) ja naisille $12(60 \%)$. Kaikki naisille korvatut ammattitaudit johtuivat nautakarjatalouden töistä tapahtuneesta altistumisesta joko fysikaalisille, kemiallisille tai biologisille taudin aiheuttajille. Miesten ammattitaudit johtuivat pääasiassa muissa maatilan töissä tapahtuneesta altistumisesta.

\section{Työtapaturmien riskitekijät}

Kartoitetuista 92 muuttujasta 34 oli vakioimattomassa logistisessa regressiomallissa tilastollisesti suuntaa-antavasti $(\mathrm{p}<0,10)$ ja niistä 25 oli merkitsevästi $(\mathrm{p}<0,05)$ yhteydessä kohonneeseen työtapaturmariskiin. Tilan sijainti C1-C4-tukialueella (vs. A- tai B-tukialue) ja maatalousyrittäjän pitkä MYEL-vakuutettu työura (yli 25 v) olivat merkitsevästi yhteydessä kohonneeseen työtapaturmariskiin. Näihin hallinnollisiin riskitekijöihin maatalousyrittäjä ei voi enää vaikuttaa.

Tukialueen ja vakuutusvuosien suhteen vakioituun malliin otettiin mukaan kaikki muut yksittäin tarkasteltuina vähintään suuntaa-antavasti merkitsevät muuttujat. Osittain vakioituun malliin jäi 13 muuttujaa, jotka olivat merkitsevästi yhteydessä kohonneeseen työtapaturmariskiin. Seuraavassa käydään läpi nämä muuttujat alenevassa merkittävyysjärjestyksessä. Maatalousyrittäjä voi omilla toimenpiteillään ainakin jossain määrin vaikuttaa niistä kaikkiin.

Niillä maidontuottajilla, jotka kokivat nykyisen työkykynsä alentuneeksi verrattuna elinikäiseen parhaimpaan, oli selvästi kohonnut työtapaturmariski (OR: 33.33; CI: 2.49-500.00). Alentuneeksi koettu työkyky voi altistaa työtapaturmille ja toisaalta työtapaturmat voivat alentaa koettua työkykyä. Karttunen ja Rautiainen (2011) totesivat työtapaturmien sekä lääkärin toteamien tautien ja sairauksien olevan vahvasti yhteydessä alentuneeseen työkykyyn maidontuottajilla.

Käsillä olevassa tutkimuksessa maidontuottajan ikääntymisellä oli vahva yhteys korkeaan vakuutusvuosien määrään, mutta regressiomallissa vain jälkimmäinen oli merkitsevästi yhteydessä kasvaneeseen työtapaturmariskiin. Se että ikä ei ollut yhteydessä riskiin, johtunee tutkimusasetelmasta.

Alkoholin käyttö viikoittain tai ainakin satunnaisesti oli absolutismiin verrattuna selvästi yhteydessä kohonneeseen työtapaturmariskiin. Alkoholia viikoittain käyttävistä valtaosa käytti sitä maltillisesti. Vastaus ei sulje pois mahdollisuutta alkoholin päivittäiseen käyttöön, jonka on todettu olevan yhteydessä kasvaneeseen työtapaturmariskiin maatalousyrittäjillä (Stallones ja Xiang 2003).

Niillä maidontuottajilla, joilla oli hylättyjä MATA-korvaushakemuksia, oli kohonnut työtapaturmariski. Tämä hallinnollinen muuttuja selittyy sillä, että valtaosalla vahingoittuneista maidontuottajista oli hylättyjä korvaushakemuksia sekä oman ilmoituksensa että MATA-rekisterin mukaan.

Selitys sille, miksi useimpien maatilatalouden töiden teko pariskunnan yhteisvoimin, sukupuolittuneemman töiden jaon sijaan, oli yhteydessä sekä kohonneeseen työtapaturmaettä ammattitautiriskiin, voi löytyä muista tilan töiden organisointiin vaikuttavista tekijöistä kuten vastaajien iästä, tila- ja karjakoosta, navettatyypistä ja tuotantotekniikasta.

Hengityselinsairauksien sekä tule-sairauksien tai vastaavien ja niihin liittyvien kiputilojen yhte- 
ys kohonneeseen työtapaturmariskiin on ymmärrettävä. Sairaudet ja kiputilat voivat liittyä raskaaseen ja kuluttavaan työhön vanhentuneissa tuotantotiloissa, joissa voi esiintyä työtapaturmien riskitekijöiden lisäksi myös hengitysteitä kuormittavia työympäristön altisteita.

Niillä maidontuottajilla, joilla ei ollut yo-tutkintoa, jotka ohjeistivat lomittajat heikosti tai joille jäi maataloustöiltä omaa vapaa-aikaa riittämättömästi, oli kohonnut työtapaturmariski. Ylioppilastutkinnon suorittaminen voi liittyä keskimääräistä alempaan ikään tai kasvaneisiin valmiuksiin hakea ja omaksua työturvallisuuteen liittyvää tietoa, jolloin tutkinnon puute voi välillisesti lisätä tapaturmariskiä. Maatalouslomittajien heikko ohjeistus voi liittyä iäkkäisiin tuotantotiloihin, jotka kasvattavat tapaturmariskiä. Riittämättömäksi koettu vapaa-aika voi liittyä puutteelliseen työstä palautumiseen sekä pitkiin työpäiviin ja altistumisaikoihin mahdollisesti keskimääräistä riskialttiimmassa työympäristössä.

Kohonneeseen työtapaturmariskiin olivat yhteydessä myös kuivan heinän päivittäinen käyttö nautojen ruokinnassa, aktiivinen sosiaalinen elämä, melko tai erittäin suureksi koettu ammattitautiriski, sarvekas karja ja päivittäinen lääkkeiden käyttö aiemmin mainittujen sairauksien, kiputilojen tai muiden syiden takia (OR: 5.03; CI: 1.09-23.26). Kuivan heinän käyttö, karjan sarvekkuus ja kasvaneeksi koettu ammattitautiriski voivat liittyä vanhentuneisiin ja riskialttiisiin tuotantotiloihin. Lääkkeiden käytön yleensä ja erityisesti reseptilääkkeiden kuten uni- ja kipulääkkeiden käytön on todettu olevan yhteydessä kasvaneeseen työtapaturmariskiin (Voaklander ym. 2009). Aktiivisen sosiaalisen elämän roolia riskitekijänä tarkastellaan alla olevassa kappaleessa.

\section{Ammattitautien riskitekijät}

Muuttujista 20 oli vakioimattomassa logistisessa regressiomallissa tilastollisesti suuntaa-antavasti $(p<0,10)$ ja niistä 13 oli merkitsevästi $(p<0,05)$ yhteydessä kohonneeseen ammattitautiriskiin.

Tilan sijainti C1-C4-tukialueella ja maatalousyrittäjän pitkä MYEL-vakuutettu työura olivat merkitsevästi yhteydessä työtapaturmien lisäksi myös kohonneeseen ammattitautiriskiin. Tukialueen ja vakuutusvuosien suhteen vakioituun malliin otettiin mukaan kaikki muut yksittäin tarkasteltuina vähintään suuntaa-antavasti merkitsevät muuttujat.

Vakioidussa mallissa oli kohonneeseen ammattitautiriskiin merkitsevästi yhteydessä neljä muuttujaa, jotka olivat alenevassa merkittävyysjärjestyksessä tule-sairauksien tai vastaavien sekä niihin liittyvien kiputilojen olemassaolo (OR: 26.75; CI: 1.60-448.69), useimpien maatilatalouden töiden teko sekä isännän että emännän voimin, päivittäinen lääkkeiden käyttö sekä aktiivinen sosiaalinen elämä (OR: 15.49; CI: 1.13-211.89).

Tule-sairauksien tai vastaavien sekä niihin liittyvien kiputilojen olemassaolon, päivittäisen lääkkeiden käytön ja kasvaneen ammattitautiriskin yhteys on ymmärrettävä. Muuttujan kattamat sairaudet tai kiputilat joko liittyvät ammattitauteina korvattaviin samankaltaisiin sairauksiin tai ne itse korvataan ammattitauteina.

Aktiivinen sosiaalinen elämä (perheen ulkopuolisten tapaaminen kyläilyn, harrastusten tai luottamustoimien merkeissä yleensä viikoittain) oli yhteydessä sekä kasvaneeseen työtapaturma- että ammattitautiriskiin. Yleinen sosiaalinen aktiivisuus voi olla yhteydessä keskimääräistä parempiin valmiuksiin hankkia hoitoa työperäisiin vammoihin tai oireisiin sekä hankkia korvauksia niistä aiheutuviin kuluihin. Iäkkäämmillä maidontuottajilla voi olla työ- ja perhe-elämän ruuhkavuosia eläviä nuorempia kollegoitaan paremmin aikaa kyläilyyn, harrastuksiin tai luottamustoimiin - sosiaalisen elämän aktiivisuus oli selvästi yhteydessä korkeampaan ikään.

\section{Tyyppikuvaukset}

Tässä tutkimuksessa todettujen riskitekijöiden ja suojelevien tekijöiden avulla laadittiin tyyppikuvaukset toisaalta riskiryhmään kuuluvista ja toisaalta alentuneen riskitason omaavista maidontuottajista. Osa tunnistetuista riskitekijöistä ja suojelevista tekijöistä soveltunee sisältönsä puolesta lypsykarjatilojen lisäksi myös muiden tuotantosuuntien tilojen ja niiden omistajien ryhmittelyyn.

Riskiryhmään kuuluvat maidontuottajat: Varsinkin työtapaturma- ja jossain määrin myös ammattitautiriski on voimakkaasti kohonnut - ja ne myös koetaan kohonneeksi - pitkän ja erityisesti fyysistä työkykyä monin eri tavoin koetelleen työuran omaavilla maidontuottajilla. Tämän tutkimuksen aineistossa nämä henkilöt ovat olleet MYEL-vakuutuksessa keskimäärin 28 vuotta, antavat omalle nykyiselle työkyvylleen keskimäärin 6/10 pistettä ja valtaosalla on tule-sairauksia, kiputiloja tai hengitystiesairauksia sekä tarvetta päivittäiselle lääkitykselle. He ovat tyypillisesti kotoisin C-tukialueelta ja harjoittavat jonkin verran koneurakointia. 
Riskiryhmään kuuluvat kärsivät viikoittain tai lähes viikoittain univelasta ja kokevat maataloustöiltä jäävän vapaa-aikansa määrän riittämättömäksi - toisaalta he usein omaavat aktiivisen sosiaalisen elämän. Heillä on karjamäärältään ja peltoalaltaan korkeintaan keskikokoinen tila, joka ei ole koskaan toiminut harjoittelutilana. Useimmat maatilatalouden ruumiilliset työt tehdään pariskunnan yhteisvoimin. Tilalla on käytössä kaksi traktoria.

Karja on kokonaan tai suurelta osin sarvipäistä ja se hoidetaan varsin käsityövaltaisessa parsinavetassa. Navetassa käsitellään kuivaa heinää päivittäin ja navetan yleiskunto sekä siisteys arvioidaan tyydyttäväksi tai heikoksi. Maatalouslomittajat saatetaan ohjeistaa vain suullisesti, mikä voi olla kytköksissä navetan kokoon ja tyyppiin.

Muita henkilöön liittyviä piirteitä ovat ylioppilastutkinnon puute, johon iällä (aineistossa keskiikä 52 vuotta) lienee osuutta sekä alkoholin joko viikoittainen - useimmilla tällöin maltillinen - tai vain satunnainen käyttö esimerkiksi juhlatilaisuuksissa. Ylipaino on varsin yleistä ja se on osalla merkittävää (BMI $\geq 30,0)$. Ikä lienee yhteydessä myös siihen, että tämän riskiryhmän henkilöillä ei (enää) ole alle 18-vuotiaita lapsia, jotka osallistuisivat viikoittain maataloustöihin.

Alentuneen riskin omaavat maidontuottajat: Työtapaturma- ja jossain määrin myös ammattitautiriski on puolestaan alentunut niiden tuottajien keskuudessa, jotka ovat viimeistään 2000-luvulla laajentaneet peltoalaansa ja karjamääräänsä sekä investoineet työympäristönsä terveellisyyteen sekä turvallisuuteen. Tyypillisesti A- ja B-tukialueilta kotoisin olevilla tuottajilla voi myös olla jo pitkä (aineistossa keskimäärin 20 vuotta) työura MYEL-vakuutettuna. Heistä useimmilla on vielä paljon työvuosia jäljellä, mitä tyypillisesti hyväksi koettu työkyky ja terveys edistävät (työkyky nyt keskimäärin 8/10 pistettä, tule-sairauksia, kiputiloja, hengitystiesairauksia tai päivittäistä lääkitystä vain harvoilla).

Keskikokoista suurempi karjamäärä ja peltoala toisaalta työllistänevät riittävästi ja toisaalta tarjonnevat riittävän elannon, joten koneurakointia ei juurikaan harjoiteta. Tilalla on käytössä kolme tai jopa neljä traktoria. Univelkaa syntyy vain aika ajoin esimerkiksi peltoviljelyn sesonkikausina tai yöpoikimisten yhteydessä, ja maataloustöiltä jää omaa vapaa-aikaa keskimäärin riittävästi. Sosiaalinen elämä on kuitenkin rajallista. Tämä voi olla yhteydessä edellistä ryhmää alhaisemman keski-iän (47 v) lisäksi siihen, että useimmilla ryhmän tiloilla töihin osallistuu viikoittain alle 18-vuotiaita lapsia.

Karja on ollut kokonaan sarvetonta ainakin vuosikymmenen ajan ja se hoidetaan joko koneellistetussa parsinavetassa tai pihatossa, joista viimeksi mainitussa voi olla automatisoitu lypsy. Kuivaa heinää annetaan karjalle vain satunnaisesti niin sanottuna terveysrehuna tai ei ollenkaan. Tila on ollut aiemmin tai on parhaillaan maatalousopiskelijoiden harjoittelutila, mikä voi olla yhteydessä tilan "edustavuuteen", asenteisiin ja vuosittaiseen työmäärään, johon harjoittelijat tuovat yleensä helpotusta. Alle puolet maatilatalouden ruumiillisista töistä tehdään pariskunnan yhteisvoimin.

Lomittajia varten on tehty kirjalliset ohjeet, joita täydennetään suullisesti. Tyypillisiä henkilöön liittyviä piirteitä ovat suoritettu yo-tutkinto, johon myös iällä voi olla osuutta sekä edellistä ryhmää pidättyväisempi suhtautuminen alkoholiin - käyttö vaihtelee absolutismista hyvin maltilliseen viikoittaiseen käyttöön. Ylipaino on yleistä myös tässä ryhmässä, mutta se on lievää (BMI 25,0-29,9).

\section{Tutkimuksen vahvuudet ja rajoitteet}

Tutkimuksen vahvuutena voidaan pitää kansainvälisesti ajatellen tutkimusryhmien ainutlaatuista muodostamistapaa. Koko (vakuutettuun) työhistoriaan perustuvaa tapaus-verrokkitutkimusta ei tiettävästi ole aiemmin tehty maataloussektorilla. Tutkimusasetelman ansiosta pieni aineisto riitti lukuisten tilastollisesti merkitsevien riskitekijöiden havaitsemiseen. Kyselyn monipuolinen sisältö ja käytössä olleella tiedonkeruumenetelmällä saatu lähes aukoton vastausaineisto ovat myös tutkimuksen vahvuuksia.

Tutkimuksen heikkous on osallistujien odotettua alhaisempi määrä, mikä rajoitti aineiston tilastollista tarkastelua ja kasvatti todettujen riskitekijöiden vetosuhteiden luottamusvälejä. Riskitekijät jouduttiin selvittämään tavanomaisen 95 prosentin luotettavuustason lisäksi 90 prosentin luotettavuustasolla. Näin saatiin kuitenkin käsitys niistä riskitekijöistä, jotka olisivat voineet nousta tilastollisesti merkitseviksi vain hieman suuremmalla tutkimusaineistolla.

\section{Johtopäätökset ja suositukset}

Vallitsevan rakennemuutoksen myötä pitkän ja kuormittavan työuran pienehköillä tiloilla ja vanhentuneissa tuotantorakennuksissa tehneet karjatalousyrittäjät ovat siirtymässä eläkkeelle joko suoraan karjataloudesta tai esimerkiksi viljanviljelyn kautta. Tuotanto keskittyy harvemmille ja aikaisempaa suuremmille karjatalous- ja kasvinviljelytiloille, joissa on ollut tai on lähitulevaisuudessa välttämätöntä 
investoida nykyaikaisiin koneellistettuihin ja osin automatisoituihin tuotantorakennuksiin. Tämä ilmiö nousi selvästi esille myös tässä tutkimuksessa.

Näin ollen korvattujen työtapaturmien ja jossain määrin myös ammattitautien absoluuttisissa ja suhteellisissa määrissä viime vuosina havaittu laskusuunta voi jopa voimistua tulevaisuudessa, jos voimakkaasti maidontuotantoon ja muuhun karjatalouteen vaikuttanut rakennemuutos jatkuu. On ilmeistä, että tuotantoa jatkavien yrittäjien kohdalla perinteiset riskitekijät vähenevät ja suojelevat tekijät vahvistuvat. Vanhojen riskitekijöiden tilalle voi kuitenkin nousta uusia riskejä.

Maatalousalan opiskelijoille, neuvojille ja erityisesti työuransa alkuvaiheessa oleville yrittäjille suunnattavassa tiedottamisessa kannattaa tuoda esille tunnistettuja riskitekijöitä ja suojelevia tekijöitä. Yrittäjät voivat itsenäisesti poistaa tai hallita riskitekijöitä ja vahvistaa suojelevia tekijöitä. Näihin toimenpiteisiin sidottavat vakuutustekniset kannustimet voivat olla hyödyllisiä. Erityisesti MTH:n kannattaa jatkaa yrittäjien työkyvyn ylläpitoon ja kehittämiseen tähtääviä toimenpiteitä. Lomitushallinnon kannattaa hyödyntää tuloksia lomittajien koulutuksessa ja heidän työnsä kehittämisessä.

Jatkotutkimuksella kannattaa selvittää, mikä on todettujen riskitekijöiden ja suojelevien tekijöiden esiintyvyys eri tuotantosuunnissa ja tilakokoluokissa. Erityisen mielekästä olisi mallintaa, miten osa karjatalousyrittäjistä ja yrittäjäpariskunnista selviytyy vuosikymmeniä ilman korvattuja työtapaturmia ja ammattitautitapauksia kuten tämän tutkimuksen verrokkiryhmä.

MYEL-, MTH- ja Tike-tietojen yhdistelmä kannattaa päivittää säännöllisesti. Jos tiedetään tarkasti, missä määrin eri tuotantosuuntien ja tilakokoluokkien viljelijät ovat liittyneet MTH:oon, tiedetään myös, miten eri riskiryhmien edustajat ovat tavoitettavissa. Vakuutusteknisten kannustimien vaikutusta kannattaa tutkia usean vuoden seurantatutkimuksella.

\section{Kiitokset}

Kirjoittajat kiittävät Maatalousyrittäjien eläkelaitosta, joka rahoitti tämän tutkimuksen työturvallisuusapurahalla, ja josta saatiin tutkimuksessa käytetty tilasto- ja osoiteaineisto. Melan vakuutus- ja hyvinvointiyksikön asiantuntija Erkki Eskolalle osoitetaan erityiskiitokset suuresta avusta tämän tutkimuksen eri vaiheissa. Projektipäällikkö Kyösti Louhelaista Työterveyslaitokselta ja erikoistutkija Juha Suutarista Maa- ja elintarviketalouden tutkimuskeskuksesta kiitetään avusta kyselyn laatimisessa.

\section{Kirjallisuus}

Karttunen, J. 2011. Lypsykarjatilalla pätee perinteinen työnjako. Teho 2: 20-21.

Karttunen, J.P. ja Rautiainen. R.H. 2011. Risk Factors and Prevalence of Declined Work Ability among Dairy Farmers. J. Agric. Saf. Health. 17(3): 243-257.

Karttunen, J. ja Rautiainen, R. 2010. Työtapaturmien ja ammattitautien riskitekijät suomalaisten maatalousyrittäjien keskuudessa. Teoksessa: Hopponen, A. (toim.). Maataloustieteen Päivät 2010. Suomen Maataloustieteellisen Seuran julkaisuja no 26. $6 \mathrm{~s}$.

Lappalainen, J. ja Saarela, K-L. 2003. Tapaturmavaarat. Teoksessa: Pietiläinen, R. (toim.). Työsuojelun perusteet. Työterveyslaitos. Helsinki. s. 38-58.

Lehtola, M.M., Rautiainen, R.H., Day, L.M., Schonstein, E., Suutarinen, J., Salminen, S. ja Verbeek, J.H. 2008. Effectiveness of interventions in preventing injuries in agriculture - a systematic review and metaanalysis. Scand J Work Environ Health 34(5): 327-336.

Rautiainen, R.H., Ohsfeldt, R., Sprince, N.L., Donham, K.J., Burmeister, L.F., Reynolds, S.J., Saarimaki, P. ja Zwerling, C. 2005. Cost of compensated injuries and occupational diseases in agriculture in Finland. J Agromed 10(3): 21-29.

Rautiainen, R.H. ja Reynolds, S.J. 2002. Mortality and Morbidity in Agriculture in the United States. J Agric Saf Health 8(3): 259-276.

Sinisalo, A. 2007. Tapaturmien riski-indeksin määrittäminen suomalaisilla maatiloilla. Maa- ja elintarviketalouden tutkimuskeskus. MTT:n selvityksiä $149.65 \mathrm{~s}$.

Stallones, L., ja Xiang, H. 2003. Alcohol Consumption Patterns and Work-related Injuries Among Colorado Farm Residents. Am. J. Prev. Med. 25(1): 25-30.

Tike. 2011. Matilda maataloustilastot. Maatilarekisteri.

Virtanen, S.V., Notkola, V., Luukkonen, R., Eskola, E. ja Kurppa, K. 2003. Work injuries among Finnish farmers: A national register linkage study 1996-1997. Am J Ind Med 43: 314-325.

Voaklander, D.C., Umbarger-Mackey, M. ja Wilson, M.L. 2009. Health, Medication Use, and Agricultural Injury: A Review. Am J Ind Med 52: 876-889.

Visser, E., Pijl, Y.J., Stolk, R.P., Neeleman, J. ja Rosmalen, J.G.M. 2007. Accident proneness, does it exist? A review and meta-analysis. Accid Anal Prev 39: 556-564. 